\title{
Penggunaan asap cair sebagai pengawet alami bakso ikan tuna sirip kuning (Thunnus albacares)
}

\author{
Use of liquid smoke as a natural preservative of yellowfin tuna (Thunnus albacares) \\ meatballs
}

\author{
Fahmi Hadi Alamsyah $^{1)}$, Irfan ${ }^{1)}$, Dewi Yunita ${ }^{\text {1* }}$ \\ ${ }^{1}$ Jurusan Teknologi Hasil Pertanian, Fakultas Pertanian,Universitas Syiah Kuala, \\ Jl. Tgk. Hasan Krueng Kalee No. 3, Darussalam, Banda Aceh 23111, Indonesia \\ *Email Korespondensi: dewi_yunita@unsyiah.ac.id \\ Informasi Artikel: \\ Dikirim: 13/08/2020; disetujui: 05/02/2021; diterbitkan: 30/03/2021
}

\begin{abstract}
The purpose of this study was to determine the effect of using various types of liquid smoke on the level of preference of panelists and the total of contaminant bacteria on yellowfin tuna meatballs. The liquid smoke used came from coconut shells, corncob, and bagasse. The tuna meatballs without the use of liquid smoke were also observed as a control. The tuna meatballs were analyzed before storage, after 15 days, and after 30 days storage (temperature $5^{\circ} \mathrm{C}$ ). The research was designed by a completely randomized design (CRD) factorial pattern. The tuna meatballs were examined for organoleptic (hedonic) tests on color, flavor, taste, and texture as well as microbial tests of Staphylococcus aureus and Salmonella sp. Proximate tests (moisture content, ash content, and protein content) were carried out on meatballs with the lowest microbial total after 30 days of storage. The data obtained were analyzed using variance analysis (ANOVA). Duncan's continued Multiple Range Test (DMRT) was carried out if the treatment was significant. The results showed that adding liquid smoke to the boiling water of the meatballs can only increase the panelist's preference for color attributes. Tuna meatballs without the use of liquid smoke could not be consumed after 15 days of storage. The tuna meatballs with the addition of liquid smoke from bagasse in the boiling water have met the national standards for fish meatballs listed in SNI 7266: 2014 until 30 days of storage. The resulting yellowfin tuna meatballs had $59.76 \%$ moisture content, $1.41 \%$ ash content, and $11.8 \%$ protein content.
\end{abstract}

Keywords: fish meatballs, liquid smoke, coconut shells, corncob, bagasse.

\begin{abstract}
ABSTRAK
Tujuan dari penelitian ini adalah untuk mengetahui pengaruh dari penggunaan berbagai jenis asap cair terhadap tingkat kesukaan panelis dan jumlah bakteri kontaminan pada bakso ikan tuna sirip kuning. Asap cair yang digunakan berasal dari tempurung kelapa, bonggol jagung, dan ampas tebu. Bakso ikan tanpa penggunaan asap cair juga diamati sebagai kontrol penelitian. Bakso ikan dianalisis sebelum penyimpanan, setelah penyimpanan (suhu $5^{\circ} \mathrm{C}$ ) 15 hari dan 30 hari. Rancangan penelitian yang digunakan ialah Rancangan Acak Lengkap (RAL) pola faktorial. Bakso ikan tuna diuji organoleptik (hedonik) terhadap warna, aroma, rasa dan tekstur serta uji total mikroba Staphylococcus aureus dan Salmonella sp. Uji proksimat (kadar air, kadar abu, dan kadar protein) dilakukan pada bakso dengan total mikroba paling rendah setelah 30 hari penyimpanan. Data yang diperoleh dianalisis dengan menggunakan analisis sidik ragam
\end{abstract}


(ANOVA). Uji lanjut Duncan's Multiple Range Test (DMRT) dilakukan jika perlakuan berpengaruh nyata. Hasil penelitian menunjukkan bahwa penambahan asap cair ke dalam air rebusan bakso hanya dapat meningkatkan tingkat kesukaan panelis terhadap atribut warna. Bakso ikan tanpa penggunaan asap cair tidak dapat dikonsumsi setelah 15 hari penyimpanan. Bakso ikan yang direbus dengan penambahan asap cair yang berasal dari ampas tebu masih memenuhi standar mutu bakso ikan yang tercantum dalam SNI 7266:2017 hingga penyimpanan 30 hari. Bakso ikan tuna sirip kuning yang dihasilkan tersebut memiliki kadar air 59,76\%, kadar abu 1,41\% dan kadar protein $11.8 \%$.

Kata kunci: bakso ikan, asap cair, tempurung kelapa, bonggol jagung, ampas tebu.

\section{PENDAHULUAN}

Seiring dengan perkembangan zaman dan kesibukan masyarakat yang semakin modern, maka tidak dapat dihindari terjadinya pergeseran nilai kepuasan masyarakat terhadap unsur mutu suatu produk. Kini nilai kepuasan konsumen juga mencakup hal-hal yang terkait dengan kepraktisan dalam penyajian produk tersebut. Produk-produk olahan pangan yang pada awalnya dibuat untuk langsung dikonsumsi, kini mulai dibuat untuk menjadi produk setengah jadi yang mempunyai daya tahan yang lebih lama dan nantinya tinggal diolah secara praktis pada saat konsumen ingin mengkonsumsinya. Dengan demikian aplikasi bahan atau teknik pengawet tidak hanya menjadi kunci bagi daya tahan suatu produk pangan, tetapi juga bagi keamanan/kesehatan para konsumen.

Salah satu produk olahan pangan yang banyak dikenal dan disukai oleh semua lapisan masyarakat Indonesia adalah bakso. Bagi para penikmat bakso, bakso memiliki keistimewaan bukan hanya pada tekstur dan perpaduannya dengan kuah yang khas, namun juga pada flavor yang dicitrakan oleh bakso tersebut (Kurniawan dan Kusrahayu, 2012). Secara definisi, bakso merupakan produk makanan yang memiliki bentuk bulat atau yang lainnya yang terbuat dari campuran daging dan pati atau serealia dengan menggunakan atau tanpa tambahan bahan makanan yang diizinkan (BSN, 2017).

Sesuai dengan potensi wilayah Aceh yang mempunyai garis pantai yang panjang, maka produksi ikan tangkap dapat dijadikan sebagai bahan baku pembuatan bakso. Berdasarkan observasi lapangan, tidak semua ikan tangkap Aceh berhasil diekspor, sebagiannya dipasarkan di pasar lokal, bahkan sebagian ada juga yang terbuang atau tidak termanfaatkan, terutama pada musim hasil tangkapan ikan yang berlimpah.

Pengolahan ikan menjadi bakso bukanlah hal baru dalam diversifikasi produk olahan ikan. Pembuatan bakso dapat dilakukan baik secara konvensional maupun dengan penggunaan mesin canggih otomatis. Namun, permasalahannya adalah dalam hal daya awet bakso. Berdasarkan pengawasan yang dilakukan oleh BPOM, sering kali ditemukan produsen yang berupaya memperpanjang umur simpan bakso dengan penambahan bahan pengawet yang berbahaya yang tidak direkomendasikan penggunaannya dalam bidang pangan. Contoh bahan pengawet berbahaya yang sering ditemukan pada produk bakso atau bahan olahan pangan lainnya adalah boraks yang melebihi batas dosis yang diizinkan atau bahkan bahan pengawet formalin yang sebenarnya dipergunakan untuk mengawetkan jenazah.

Selain itu, kandungan nutrisi dan kadar air yang tinggi dapat menyebabkan bakso ikan selalu mengalami masalah terhadap masa simpannya. Kok dan Park (2007) mengatakan bahwa tingginya nutrisi pada daging ikan menyebabkan bakso ikan hanya bertahan 12-24 jam pada suhu kamar $\left(25-27^{\circ} \mathrm{C}\right)$ dan $4-5$ hari pada suhu refrigerasi $\left(4 \pm 1^{\circ} \mathrm{C}\right)$. Hasil penelitian Rahmat, Tamrin, \& Ibrahim (2017) juga menunjukkan bahwa bakso ikan tongkol yang dibuat dengan cara perendaman dalam kitosan selama 1 jam setelah perebusan hanya mampu disimpan selama 2 hari pada suhu ruang. 
Salah satu alternatif untuk bahan pengawet alami produk bakso adalah penggunaan asap cair. Penggunaan asap cair menunjukkan adanya pengaruh yang positif terhadap perpanjangan masa simpan bakso daging (Widayat, Yaqin, \& Al Baarri, 2018) dan bakso ikan kambing-kambing (Abalistes stellaris) (Ags \& Nurhayati, 2017). Asap cair tempurung kelapa juga telah diaplikasikan pada fillet ikan tuna (Sutanaya, Kencana, \& Arda, 2018) dan daging ikan gurami segar (Mu'tamar, Cahyani, \& Fakhry, 2018).

Oleh karena itu, pada penelitian ini, daya simpan bakso ikan tuna sirip kuning dikaji dengan penggunaan asap cair berbagai sumber (tempurung kelapa, bonggol jagung, dan ampas tebu). Tujuan penelitiannya adalah untuk mendapatkan asap cair yang paling disukai untuk ditambahkan pada air perebusan bakso dan yang dapat mempertahankan mutu mikroba selama penyimpanan.

\section{METODE}

\section{Bahan dan alat}

Bahan-bahan yang digunakan dalam pembuatan bakso pada penelitian ini adalah daging ikan tuna sirip kuning, tepung tapioka, air, es batu, asap cair, garam merica dan bawang putih. Ikan tuna sirip kuning diperoleh dari UD. Nagata Tuna, Banda Aceh dan digiling di CV. Aroma Food, Banda Aceh. Asap cair yang digunakan berbahan dasar tempurung kelapa, bonggol jagung, dan ampas tebu dibeli dari PT. Asap Cair Multiguna, Semarang. Sedangkan media agar yang digunakan adalah Baird Parker agar (Oxoid CM0275) untuk pengujian Staphylococcus aureus dan Xylose Lysine Deoxycholate (XLD) agar (Oxoid CM0469) untuk pengujian Salmonella sp.

Alat-alat yang digunakan dalam pembuatan bakso ikan tuna yaitu: food processor, pisau, talenan, sendok, baskom, grinder, pengaduk, gelas ukur, timbangan digital, desikator, panci besar, plastik pembungkus, sealer, cawan petri, ose, bunsen, sterilizer, kompor, penyaring, piring dan alat-alat lainnya yang umum digunakan di laboratorium untuk keperluan analisis.

\section{Metode penelitian}

Penelitian ini menggunakan Rancangan Acak Lengkap (RAL) dengan pola faktorial yang terdiri atas 2 faktor. Faktor pertama dalam penelitian ini adalah jenis asap cair yang ditambahkan pada air perebusan bakso (A) yang terdiri dari empat taraf yaitu A1 = asap cair tempurung kelapa, $\mathrm{A} 2$ = asap cair bonggol jagung, A3 = asap cair ampas tebu dan A4 = kontrol. Faktor kedua pada penelitian ini adalah lama penyimpanan $(\mathrm{H})$ pada suhu refrigerasi $\left(4^{\circ} \mathrm{C} \pm 1\right)$ yang terdiri atas tiga taraf yaitu $\mathrm{H} 1$ = sebelum penyimpanan, $\mathrm{H} 2$ = penyimpanan selama 15 hari, dan $\mathrm{H} 3=$ penyimpanan selama 30 hari. Kombinasi dari perlakuan yang diterapkan adalah 4 x 3 dengan menggunakan 3 kali ulangan (U) sehingga diperoleh 36 satuan percobaan.

\section{Pembuatan bakso}

Pembentukan adonan dilakukan dengan mencampurkan $500 \mathrm{~g}$ daging ikan, $13 \mathrm{~g}$ garam, $3 \mathrm{~g}$ merica, dan $7 \mathrm{~g}$ bawang putih dengan food processor selama 1 menit lalu ditambahkan 100g tapioka dan 100g air es secara bertahap. Adonan yang terbentuk dicetak dengan menggunakan tangan dan dengan bantuan sendok dan langsung direbus dalam air yang mengandung asap cair $(2,5 \%)$ sesuai perlakuan (asap cair yang bersumber dari tempurung kelapa, bonggol jagung, ampas tebu dan kontrol) hingga bakso mengambang dalam air rebusan. Bakso yang telah direbus kemudian diangkat dengan saringan dan dipindahkan ke dalam wadah kering untuk ditiriskan. Penyimpanan bakso dilakukan dalam kemasan plastik poliamide (nilon) tertutup dan tidak vakum dan disimpan dalam lemari pendingin dengan suhu refrigerasi $\left(4^{\circ} \mathrm{C} \pm 1\right)$ hingga analisis yang dilakukan sesuai perlakuan (sebelum penyimpanan, 15 hari penyimpanan, dan 30 hari penyimpanan).

\section{Analisis produk}

Produk bakso ikan yang dihasilkan dianalisis total cell counts (TCC) bakteri Staphylococcus aureus dan Salmonella sp. 
dan uji organoleptik (hedonik) terhadap warna, aroma, rasa dan tekstur. Namun, pengujian organoleptik (hedonik) hanya dilakukan pada sampel sebelum penyimpanan (H1) untuk setiap jenis asap cair (A). Sedangkan, pengujian organoleptik (hedonik) untuk sampel setelah penyimpanan (H2 dan $\mathrm{H} 3)$ tidak dilakukan dikarenakan keberadaan kontaminan mikroba telah melampaui ambang batas yang ditetapkan dalam SNI 7266:2014 (1x10 ${ }^{2}$ koloni/g). Bakso dengan nilai kontaminan paling rendah setelah 30 hari penyimpanan dan paling disukai oleh panelis (perlakuan terbaik) selanjutnya dianalisis kimia. Pengujian yang dilakukan pada analisis kimia meliputi pengujian kadar air, kadar abu dan kadar protein dari sampel. Pengujian kadar air dilakukan dengan metode gravimetri, kadar abu dengan metode oven dan kadar protein dilakukan dengan metode kjehdahl (AOAC, 2019).

\section{Analisis data}

Data yang diperoleh selain kontrol dianalisis dengan menggunakan analisis sidik ragam (Analysis of Variance;
ANOVA). Uji lanjut Duncan Multiple Range Test (DMRT) dilakukan untuk perlakuan yang memberikan pengaruh nyata terhadap parameter (total cell counts dan hedonik warna) yang dianalisis dengan menggunakan software IBM SPSS Statistic 22. Data hasil pengujian proksimat disajikan dengan standar deviasi (SD).

\section{HASIL DAN PEMBAHASAN}

\section{Total Cell Counts}

\section{Staphylococcus aureus}

Berdasarkan hasil sidik ragam, penambahan berbagai jenis asap cair ke dalam air rebusan bakso ikan tuna sirip kuning berpengaruh sangat nyata $(\mathrm{P}<0.01)$ terhadap nilai TCC Staphylococcus aureus. Nilai rata-rata TCC hasil pengujian yang dibandingkan dengan kontrol dan SNI 7266:2017 dapat dilihat pada Tabel 1. Namun, perlakuan lama penyimpanan dan interaksinya dengan jenis asap cair tidak memberikan pengaruh terhadap nilai TCC Staphylococcus aureus.

Tabel 1. Rata-rata total cell counts Staphylococcus aureus pada bakso ikan tuna sirip kuning. Asap Cair (A) Total cell counts Staph. aureus

\begin{tabular}{lc}
\multicolumn{1}{c}{ Asap Cair (A) } & Total cell counts Staph. aureus \\
& (koloni/g) \\
\hline Tempurung Kelapa (A1) & $1,50 \times 10^{1} \mathrm{~b}$ \\
Bonggol Jagung (A2) & $1,60 \times 10^{1} \mathrm{c}$ \\
Ampas Tebu (A3) & $1,18 \times 10^{1} \mathrm{a}$ \\
Kontrol (A4) & $1,58 \times 10^{2} \mathrm{~d}$ \\
SNI 7266:2017 & $1,00 \times 10^{2}$ \\
\hline
\end{tabular}

Keterangan: nilai yang diikuti oleh huruf yang sama menunjukkan tidak ada perbedaan.

Berdasarkan Tabel 1, seluruh nilai TCC Staph. aureus pada bakso ikan tuna sirip kuning telah memenuhi SNI 7266:2017. Namun, jika dibandingkan antar taraf penelitian, penggunaan asap cair ampas tebu mampu menghambat nilai TCC Staph. aureus lebih baik dibandingkan asap cair tempurung kelapa dan bonggol jagung. Menurut Kristinsson, Danyali, \& UaAngkoon (2007), kemampuan asap cair sebagai antimikroba disebabkan oleh kandungan fenol dan asam yang terkandung di dalamnya. Menurut Wang, Koseki, Chung, \& Oh (2017), kelompok
Staphylococci sangat sensitif terhadap nutrisi tempat tumbuhnya. Oleh karena itu, kandungan fenol dan asam pada asap cair ampas tebu diduga lebih tinggi dari kedua asap cair lainnya.

\section{Salmonella sp.}

Berdasarkan hasil sidik ragam, kedua faktor penelitian tidak memberikan pengaruh $(\mathrm{P} \geq 0,01)$ terhadap nilai TCC Salmonella sp. Bakteri patogen ini tidak ditemukan pada seluruh sampel yang diuji termasuk kontrol. Hal ini menunjukkan bahwa bakso ikan tuna sirip kuning yang dihasilkan dari penelitian 
memiliki kualitas yang baik. Menurut Poeloengan, Komala, \& Noor (2014), kontaminan Salmonella sp. pada bahan pangan umumnya disebabkan oleh proses penanganan bahan baku dan pengolahan yang tidak higenis.

\section{Uji organoleptik (hedonik)}

Hasil penelitian menunjukkan bahwa variasi jenis asap cair tidak memberikan pengaruh terhadap terhadap aroma, rasa dan tekstur bakso ikan tuna sirip kuning yang dihasilkan. Namun, perlakuan variasi jenis asap cair memberikan pengaruh secara sangat nyata terhadap warna. Hasil ini berbeda dengan hasil penelitian Riyadi \& Atmaka (2010) di mana perbedaan konsentrasi asap cair yang berasal dari tempurung kelapa memberikan nilai sensori yang berbeda terhadap rasa dan aroma bakso ikan tenggiri.

Bakso ikan umumnya memiliki warna putih keabu-abuan dengan permukaan yang licin. Berbeda dengan bakso ikan pada umumnya, bakso ikan tuna memiliki warna abu-abu pekat dan cenderung lebih gelap dikarenakan warna daging tuna yang terdiri atas dua warna daging, yaitu merah dan putih keabu-abuan. Warna alami bakso ikan tuna yang cenderung gelap memberikan dampak terhadap penilaian panelis sehingga nilai ujinya cenderung lebih rendah dibandingkan sampel yang direbus dalam larutan asap cair. Gambar 1, nilai kesukaan panelis terhadap bakso ikan tanpa penambahan asap cair saat perebusan menghasilkan nilai paling rendah $(2,38$; tidak suka).

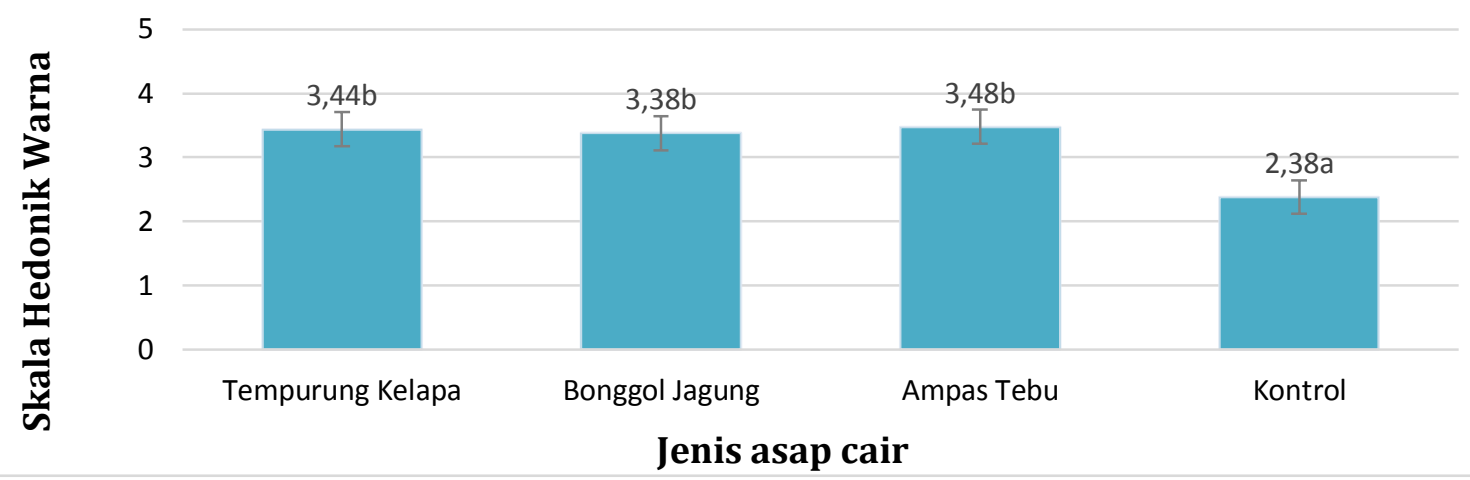

Gambar 1. Nilai uji organoleptik (hedonik) warna bakso ikan tuna sirip kuning dengan skor $1=$ Sangat Tidak Suka, $2=$ Tidak Suka, $3=$ Agak Suka, $4=$ Suka, $5=$ Sangat Suka (nilai yang diikuti oleh huruf yang sama menunjukkan tidak ada perbedaan).

Penambahan asap cair tempurung kelapa, bonggol jagung, ampas tebu menghasilkan nilai sensori warna bakso ikan tuna secara berturut 3,44, 3,38, dan 3,48 di mana nilai tersebut agak disukai oleh panelis jika dibandingkan dengan kontrol penelitian. Hasil penelitian juga menunjukkan nilai sensori warna tertinggi dimiliki oleh sampel dengan perlakuan perebusan dalam larutan asap cair ampas tebu. Hal tersebut diduga karena penambahan asap cair dapat mengakibatkan senyawa karbonil masuk ke dalam bahan sehingga membentuk warna keabu-abuan yang khas pada produk (Utami et al., 2016).

\section{Perlakuan terbaik}

Nilai kontaminan paling rendah setelah 30 hari penyimpanan dan paling disukai oleh panelis adalah kombinasi perlakuan $\mathrm{A} 3 \mathrm{H} 3$ yaitu bakso ikan tuna sirip kuning yang direbus dengan penambahan asap cair ampas tebu yang dianalisis kimianya setelah 30 hari penyimpanan pada suhu $40^{\circ} \mathrm{C} \pm 1$. Nilai aspek mutu kimia yang meliputi kadar air, kadar abu dan kadar protein dari perlakukan terbaik yang dibandingkan dengan SNI 7266:2017 dan beberapa literatur dapat dilihat pada Tabel 2 . 
Tabel 2. Perbandingan komposisi kimia perlakuan terbaik

\begin{tabular}{cccccc}
\hline Aspek Mutu & $\begin{array}{c}\text { Perlakuan } \\
\text { Terbaik } \\
\text { (A3H3) }\end{array}$ & $\begin{array}{c}\text { SNI } \\
7266: 2017\end{array}$ & $\begin{array}{c}\text { Aziza } \text { al. }(2015) \\
\text { Riyadi dan }\end{array}$ & $\begin{array}{c}\text { Atmaka } \\
(2010)\end{array}$ & $\begin{array}{c}\text { Poernomo } \\
\text { et al. } \\
(2013)\end{array}$ \\
\hline Kadar Air (\%) & $59,76 \pm 0,14$ & Maks. 65 & 67,3 & 75,06 & 71,18 \\
Kadar Abu (\%) & $1,41 \pm 0,06$ & Maks. 2 & 2,17 & - & 1,39 \\
Kadar Protein (\%) & $11,8 \pm 0,09$ & Min. 7 & 10,81 & 10,16 & 8,37 \\
\hline
\end{tabular}

Keterangan: $\mathrm{A} 3 \mathrm{H} 3$ = Bakso ikan tuna sirip kuning yang direbus dengan penambahan asap cair ampas tebu yang dianalisis kimianya setelah 30 hari penyimpanan pada suhu $4^{\circ} \mathrm{C} \pm 1$.

Secara keseluruhan bakso ikan yang dihasilkan telah memenuhi persyaratan mutu kimia pada SNI 7266:2017 (kadar air maksimal $65 \%$, kadar abu maksimal $2 \%$, dan kadar protein minimal 7\%). Namun, berdasarkan data pada Tabel 2, bakso ikan tuna yang diuji pada penelitian ini memiliki nilai kadar air yang lebih rendah dan kadar protein yang lebih tinggi dibandingkan dengan bakso ikan tongkol (Aziza et al., 2015), bakso ikan tenggiri (Riyadi dan Atmaka, 2010), dan bakso ikan layaran (Poernomo et al., 2013). Perbedaan kadar air dan kadar protein bakso ikan tuna sirip kuning yang dihasilkan dibandingkan dengan bakso ikan lainnya diduga karena perbedaan komposisi bahan baku dan bahan tambahan yang digunakan selama proses pembuatan.

Penentuan kelayakan mutu bakso tidak hanya dapat diketahui melalui pengujian berbasis laboratorium, namun dapat dilakukan secara sederhana. Bakso yang sudah tidak layak dikonsumsi dapat dikenali dengan adanya lapisan lendir pada permukaan bakso. Terbentuknya lapisan lendir mengindikasikan bahwa produk tersebut telah mengalami kemunduran mutu akibat aktivitas bakteri, sehingga sebaiknya tidak dikonsumsi lagi (Kok dan Park, 2007).

\section{KESIMPULAN}

Berbagai jenis asap cair yang ditambahkan ke dalam air rebusan bakso ikan tuna dapat menurunkan jumlah kontaminan Staphylococcus aureus secara nyata $(\mathrm{P}<0,01)$ baik sebelum penyimpanan maupun setelah penyimpanan 15 dan 30 hari. Bakso ikan yang direbus tanpa penambahan asap cair tidak layak lagi dikonsumsi setelah penyimpanan selama 15 hari karena total Staphylococcus aureus (1,8 x $10^{2}$ koloni/g) telah melebihi syarat SNI 7266:2017 (Maks $\left.1,0 \times 10^{2} \mathrm{koloni} / \mathrm{g}\right)$. Bakso yang direbus dalam larutan asap cair tempurung kelapa, bonggol jagung maupun ampas tebu mampu mengurangi jumlah kontaminan Staphylococcus aureus secara signifikan hingga penyimpanan 30 hari pada suhu $4^{\circ} \mathrm{C} \pm 1$.

\section{UCAPAN TERIMA KASIH}

Penulis mengucapkan terima kasih kepada UD. Nagata Tuna atas bahan baku daging ikan tuna sirip kuning dan $\mathrm{CV}$. Aroma Food untuk proses penggilingan daging ikan.

\section{DAFTAR PUSTAKA}

Ags, D. A., \& Nurhayati. (2017). Daya terima dan kandungan mutu bakso ikan kambing-kambing (abalistes stellaris) dengan penambahan asap cair dan simpan suhu dingin. Acta Aquatica, 4(2), 59-62.

AOAC. (2005). Official methods of analysis. (B.F. Station, Ed.). Washington DC, USA: Association of Official Analytical Chemists, Inc.

Aziza, T., Affandi, D. R., \& Manuhara, G. J. (2015). Bakso ikan tongkol (euthynnus affinis) dengan filler tepung gembili sebagai fortikan inulin. Jurnal Teknologi Hasil Pertanian, 8(2), 7783.

BSN. (1995). SNI 7266 Bakso Daging. Jakarta. 
Kok, T. N., \& Park, J. W. (2007). Extending the shelf life of set fish ball. Journal of Food Quality, 30, 1-27.

Kristinsson, H. G., Danyali, N., \& UaAngkoon, S. (2007). Effect of filtered wood smoke treatment on chemical and microbial changes in mahi mahi. Journal of Food Science, 72, 16-24.

Kurniawan, \& Kusrahayu. (2012). Kadar serat kasar, daya ikat air, dan rendemen bakso ayam dengan penambahan karaginan. Jurnal Aplikasi Teknologi Pangan, 1(2), 12-17.

Mu'tamar, M. F. F., Cahyani, I. G., \& Fakhry, M. (2018). Aplikasi asap cair batang tembakau (nicotiana tabacum 1.) untuk memperpanjang umur simpan daging ikan gurami segar. Industria: Jurnal Teknologi Dan Manajemen Agroindustri, 7(3), 181-188.

Poeloengan, M., Komala, I., \& Noor, S. M. (2014). Bahaya salmonella terhadap kesehatan. Yogyakarta, Indonesia: Balai Penelitian Veteriner.

Poernomo, D., Suseno, S. H., \& Subekti, B. P. (2013). Karakteristik fisika kimia bakso dari daging lumat ikan layaran (istiophorus orientalis). Jurnal Pengolahan Hasil Perikanan Indonesia, 16(1), 58-68.

Rahmat, S., Tamrin, \& Ibrahim, M. N. (2017). Pengarih penambahan kitosan dan lama penyimpanan bakso ikan tongkol (euthynnus affinis c.) terhadap nilai organoleptik, kadar air, dan jumlah bakteri. Jurnal Sains Dan Teknologi Pangan, 2(2), 444-457.

Riyadi, N. H., \& Atmaka, W. (2010). Diversifikasi dan karakterisasi citarasa bakso ikan tenggiri (scomberomus commerson) dengan penambahan asap cair tempurung kelapa. Jurnal Teknologi Hasil Pertanian, 3(1), 1-12.

Sutanaya, N. T. A., Kencana, P. K. D., \& Arda, G. (2018). Aplikasi asap cair tempurung kelapa mampu meningkatkan umur simpan fillet ikan tuna. Jurnal Beta (Biosistem dan Teknik Pertanian), 6(2), 82-89.
Utami, R. D., Tamrin, \& Isamu, K. T. (2016). Efek Perendaman vakum asap cair pada bakso ikan tuna (thunnus sp.) terhadap penyimpanan. Jurnal Sains dan Teknologi Pangan, 1(3), 193-200.

Wang, J., Koseki, S., Chung, M.-J., \& Oh, D.-H. (2017). A novel approach to predict the growth of staphylococcus aureus on rice cake. Frontiers in Microbiology, 8, 1140.

Widayat, W., Arifiani, S. N., Yaqin, N., \& Al Baarri, A. N. (2018). Study of utilization liquid smoke and carragenan as a natural antibacterial in manufacturing beef meatballs. IOP Conference Series: Earth and Environmental Science, 102, 12060. 